Article

\title{
Coeducational Methodology Used by Physical Education Teachers and Students' Perception of It
}

\author{
Pedro Valdivia-Moral ${ }^{1, *}\left(\mathbb{D}\right.$, David Molero ${ }^{2}$, Arturo Díaz-Suarez ${ }^{3}$, Cristian Cofre $^{4}$ \\ and Maria Luisa Zagalaz-Sánchez 5 (iD) \\ 1 Department of Didactics of Musical, Plastic and Body Expression, University of Granada, \\ Faculty of Education, Campus Universitario Cartuja, s/n, 18071 Granada, Spain \\ 2 Department of Pedagogy, University of Jaen, Faculty of Humanities and Education Sciences, \\ Campus Las Lagunillas, s/n, 23071 Jaén, Spain; dmolero@ujaen.es \\ 3 Department of Physical Activity and Sport, University of Murcia, Faculty of Sport Science, Calle Argentina, \\ 19, 30720 San Javier, Murcia, Spain; ardiaz@um.es \\ 4 Facultad de Ciencias Médicas Universidad de Santiago, Escuela de Ciencias del Deporte Universidad Santo \\ Tomás Santiago de Chile, Santiago de Chile, Chile; cristian.cofre@usach.cl \\ 5 Department of Didactics of Musical, Plastic and Body Expression, University of Jaen, Faculty of Humanities \\ and Education Sciences, Campus Las Lagunillas, s/n, 23071 Jaén, Spain; lzagalaz@ujaen.es \\ * Correspondence: pvaldivia@ugr.es; Tel.: +349-5824-4273
}

Received: 31 May 2018; Accepted: 26 June 2018; Published: 4 July 2018

check for updates

\begin{abstract}
Background: In physical education (PE), the methodology used to develop coeducation must consider the tastes and preferences of students. The purpose of this work was to analyze how teachers work with different aspects of PE classes and how their work is perceived by students. Methods: The sample was formed of 176 teachers and 1136 secondary school students. The research design was descriptive. The instruments used were the Questionnaire of Coeducational Aspects in Physical Education for teachers and the Questionnaire of Perception of Equality and Discrimination in Physical Education for Students. Results: The different statistical analyses showed significant differences in how male and female teachers assigned responsibility to the students. With regard to the students, significant differences were found between boys and girls in their opinions of how their teachers apply the same rules to all the students. Conclusions: Differences exist between male and female teachers in regard to control of the area used for motor activity. With regard to the students, girls perceive to a greater extent than their male counterparts that the activities in PE classes promote equality in the improvement of their capacities.
\end{abstract}

Keywords: physical education; coeducation; equality

\section{Introduction}

The school reproduces male culture and values, thus instilling a series of gender stereotypes among students [1,2]. For this reason, it is vital that the schools themselves and particularly their teaching staff, should assimilate any necessary changes in order to pass on the concept of equality to students. The influence of teaching staff is determined by the acceptance of the established rules by students [3,4]. Physical Education (PE) classes encourage higher interaction among students, which can lead to the perception of stereotypes that may go unnoticed in other classes [4].

Currently PE teachers do not offer a realistic, alternative answer to the gender issues occurring in class. Previous related research carried out in Spain [5-9], showed that the PE teaching staff still has sexist prejudices, which may have an impact on the education of students by the reinforcement of stereotypes that promote inequality [10]. This is due to the fact that gender inequalities and 
stereotyping are part of teachers' own experiences in both PE and sport participation in school and their education as PE student teachers [11]. The influence of teachers on students has previously been studied in Spain by Castillo and Corral [12] and Castillo, Romero, González and Campos [13] and in other countries by Chen and Rao [14] and, Lentillon, Cogérino and Kaestner [15].

The methodology used by teachers to work on coeducation must take into account the tastes and preferences of students, not only from the point of view of gender but also according to their individual preferences, as pointed out by Álvarez and Costa [16]. It is for this reason that the present study considers those factors that have an effect on the gender stereotypes that may be present in PE. Those factors have been studied focusing on structural aspects of PE classes such as content, activities, use of space, student grouping, materials, evaluation, feedback and language. They have been studied by Spanish authors [8,13,17-19], European authors [15] and American authors [20,21]. The importance of analyzing such aspects is highlighted by the conclusions drawn by the studies of Rebollo, García-Pérez, Piedra and Vega [22], who stated that the methodological aspects applied by teachers are lacking in coeducational perspective.

In continuation, the roles of the teaching staff and the student body are analyzed in relation to the different variables that are the object of this study.

The first variable is the activities that are developed in PE classes. However, given the importance that the activities proposed by PE teaching staff in their classes [8], they deserve special analysis. There exist studies focusing on the role of the student from a coeducational perspective. Against this background Kirk and Oliver [11] indicate that boys dominated co-ed classes and that perspectives on the gender appropriateness of activities remain in place. It is because of this that Mckenzie et al. [23] indicate that changes may be needed for girls, such as including activities more preferred by girls. In respect to the educators, female teachers practice slightly different teaching styles, with women engaging with girls in more interpersonal ways, in contrast to male teachers' more direct instructional styles [11].

We understand the use of motor space as what is used during participation in a task is an important variable. Therefore, we focus our attention on each gender's use of the motor space. Thus, as Cantó and Ruiz [24] indicate, in the space used for the development of motor behaviors, different processes of socialization are established in addition to the occupation and use of the space in relation to sexual stereotypes. Additionally, Colwell [25] indicates that separating the students in the activities area can be considered discrimination. An alternative to these problems is suggested by Moreno, Alonso and Martínez-Galindo [26], who suggest as a solution to different motor space problems the use of space rotation.

Forming of groups is an aspect of great important to education equality as integration in a group is essential to the socialization of an individual and therefore to the construction of gender equality. In these groups roles, stereotypes and attitudes are established, developing the student body image and thus their self-concept [27]. There are few works that relate the attitudinal development of the students to the structure of the groups in relation to gender. In the Spanish context, Torres [4] demonstrates that activities in which the forming of groups is mixed, male students just as much as female students opposed being partnered with a classmate of the opposite sex, a trend accentuated among immigrant students. Lastly, it is indicated that forming of groups spontaneously results in groups of the same sex, reflecting reluctant attitudes toward mixed groups where the male "aggression" becomes "sexual aggression" and the girls are exposed to comparative and degenerative mocking looks [28].

Another variable analyzed is material. There exist materials whose use are linked to one sex or another, for example dumbbells in the case of boys and rhythmic gymnastics clubs in the case of girls [8]. Ariel [28] indicates that the males are, in the majority of the cases, those who seek out the materials (balls, cones, ropes ... ) and grab and manipulate them even before the teacher takes roll. In contrast, there have not been similar actions observed in the females. Textbooks are a part of the material that impact gender equality in the transmission of sexist stereotypes. "Games and Sports" section, more attention is given to team sports, which are traditionally associated with the male gender than individual artistic sports [29]. 
The next variable is the evaluation. When an evaluation is done based on terms of athletic performance, the physiological advantages of the male gender are being valued above the female gender [8]. According to Moreno et al. [26], teachers should avoid quantitative evaluation, seeking instead qualitative evaluation that takes into account aspects such as participation, respect and /or appreciation of their own chances against competitive aspects. An evaluation should be done as individually as possible, seeking a rating based on the progress of the student.

The feedback that is given to the student body can be influenced by gender stereotypes. The investigation of Castillo and Corral [12] is a relevant work for the variable because it can be emphasized that the PE teaching staff provides a similar number of feedbacks to boys as to girls. Alternatively, the channel most used is auditory, containing evaluative and descriptive objectives in an individual way for each student. In addition, they point out that feedback provokes higher implication, motivation and expectations in the students.

The last variable is Sexist Language. According to Álvarez-Bueno et al. [30], there exists discrimination by the part of the teaching staff toward female students in the use of language in PE classes. We agree with Castillo, Romero, González and Campos [31] in affirming that use of the masculine pronoun form in naming this reality, we hide one of the genders and we are discriminating against building contexts where both sexes are developed. PE teaching staff interacts more with boy students than with girl students [20]. In the investigation of Koca [32] it is indicated that in mixed classes the boys have more verbal interaction with the teachers.

Once all the variables involved in the study are analyzed the proposed theories reinforce the need of studies and working plans that support the coeducational training of teaching staff. The results of this study can be used for such training and have been requested for decades by many authors who insist on the introduction of methodological changes to develop specific programs [19,30].

The references cited above certainly justify this study. From a social point of view and in relation to the influence that the different gender stereotypes may have on the students' school life, it is important to know whether the activities proposed by teachers reinforce or, on the contrary, try to confront sexist prejudices. Because of this, the student's perception of the coeducational approach of the teacher is fundamental to this work. Likewise, the methodology utilized in the investigation presents an alternative to conventional studies, as it analyzes the opinion of the educator about their own work and on the other hand, the student's perception of equality and discrimination. The use of questionnaires made it possible to access two samples of a size that is representative of the teaching staff and students of the province of Jaén, in the south of Spain.

This study is further justified by the fact that no previous research has been carried out in Spain that analyzes the impact of the teaching staff's work on the PE classes from a gender perspective. Furthermore, the area in question, $\mathrm{PE}$, plays a critical role in the acquisition of sexist values not only because gender stereotypes are encouraged in PE class but because there exist physical differences in the sexes resulting from the particular anatomy and physiology of each gender. Often PE classes in Spain reinforce gender stereotypes by associating activities of strength, speed and endurance to boys while associating activities of flexibilities, rhythm and body language to girls [13]. Therefore, the aim of the study was to analyze how teaches work with different aspects of class and how students perceive this work. Thus, the hypotheses posed in terms of the analyzed variables are:

Hypothesis 1. Female teachers try more than male teaches to make their class activities more coeducational.

Hypothesis 2. Female teachers concentrate on the control of the area used for motor activity more than male teachers.

Hypothesis 3. Male teachers utilize materials, class grouping, language, evaluation and feedback to work on coeducation more than female teachers.

Hypothesis 4. Female students perceive more discrimination than male students, in the activities planned by the teaching staff. 
Hypothesis 5. Male students perceive more equally than female students in the utilization of materials, class grouping, language, evaluation and feedback from the teaching staff.

Hypothesis 6. The female students perceive more than male students that their teachers utilize sexist language.

\section{Methodology}

\subsection{Sample}

Two types of participants were involved in this study, one being the secondary school students and the other being secondary school PE teachers. Both samples were selected from coed educational centers in the province of Jaén, in the south of Spain. As a result, two educational centers that impart same-sex classes were excluded.

In respect of teaching staff, it is noted that all subjects were white, from the middle socioeconomic class and represented by both sexes. The number of teachers in the study population was $n=213$, all of them from the province of Jaén. The data producing sample was formed by 176 teachers $(n=176)$, representing $82.6 \%$ of the total population. Table 1 demonstrates the characteristics of the sample of teaching staff according to their sex.

Table 1. Distribution of the teaching staff sample according to sex.

\begin{tabular}{cccc}
\hline & Category & Men, $\boldsymbol{n}(\mathbf{\%})$ & Women, $\boldsymbol{n} \mathbf{( \% )}$ \\
\hline \multirow{2}{*}{ Age } & Under 30 & $25(18.8 \%)$ & $14(32.6 \%)$ \\
& More than 30 and less & $54(40.6 \%)$ & $13(30.2 \%)$ \\
& than 40 & $54(40.6 \%)$ & $16(37.2 \%)$ \\
\hline \multirow{2}{*}{ Years of experience } & More than 40 & $28(21.1 \%)$ & $14(32.6 \%)$ \\
& Less than 5 & $24(18 \%)$ & $7(163 \%)$ \\
& Between 4 and 10 & $81(60.9 \%)$ & $22(51.1 \%)$ \\
\hline Total & More than 10 & $133(75.6 \%)$ & $43(24.4 \%)$ \\
\hline
\end{tabular}

Regarding students, simple probability sampling was carried out with a sample that contained secondary school students from the province of Jaén who attended school on the day the questionnaire was given. As with the teachers, data from all of the regions of the province were obtained by applying the questionnaire in cities of the same type as those used in the collection of data for the teachers. As to the characteristics of the students, the following was noted; (A) students' race varied, with individuals of white, black, Asian, Latino and eastern European decent; (B) they were from high, middle and lower socioeconomic classes; (C) both sexes were represented.

In order for the sample to be representative of the province of Jaén, the formulas of Fox [33] and León and Montero [34] were used, which indicated that the sample size should be $n=1031$ for it to be representative, with a confidence level of $95 \%$ and an error of $3 \%$. The sample was made up of 1136 secondary school students. The sociodemographic characteristics of the students can be seen in Table 2.

Table 2. Distribution of the student sample by sex.

\begin{tabular}{cccc}
\hline & Category & Men, $\boldsymbol{n} \mathbf{( \% )}$ & Women, $\boldsymbol{n} \mathbf{( \% )}$ \\
\hline & 12 & $102(16.7 \%)$ & $113(21.4 \%)$ \\
Age (mean = 13.8) & 13 & $154(25.3 \%)$ & $145(27.5 \%)$ \\
& 14 & $165(27.1 \%)$ & $99(18.8 \%)$ \\
& 15 & $119(19.5 \%)$ & $113(21.4 \%)$ \\
& 16 & $53(8.7 \%)$ & $53(10.1 \%)$ \\
& 17 & $16(2.6 \%)$ & $4(0.8 \%)$ \\
\hline
\end{tabular}


Table 2. Cont.

\begin{tabular}{cccc}
\hline & Category & Men, $\boldsymbol{n} \mathbf{( \% )}$ & Women, $\boldsymbol{n} \mathbf{( \% )}$ \\
\hline \multirow{3}{*}{ Course } & $1^{\circ}$ & $199(32.7 \%)$ & $185(35.1 \%)$ \\
& $2^{\circ}$ & $175(28.7 \%)$ & $146(27.7 \%)$ \\
& $3^{\circ}$ & $147(24.1 \%)$ & $100(19 \%)$ \\
& $4^{\circ}$ & $88(14.5 \%)$ & $96(18.2 \%)$ \\
\hline \multirow{2}{*}{ Type of Center } & Public & $433(71.1 \%)$ & $406(77 \%)$ \\
& Charter School & $176(28.9 \%)$ & $121(23 \%)$ \\
\hline Total & & $609(53.06 \%)$ & $527(46.94 \%)$ \\
\hline
\end{tabular}

\subsection{Instruments}

A questionnaire was used for each sample. In the case of the teaching staff, the Questionnaire of Coeducational Aspects in Physical Education (CACEF) was used [9]. This questionnaire has three dimensions that assess: (a) coeducational trends and elements that influence coeducation; (b) contained values and factors that are part of the process; (c) coeducational methodology in PE. It has 44 items, organized through 1 to 10 on the Likert scale. In this study, the questionnaire showed a Cronbach's alpha value of 0.814 in all of its items [8] therefore fulfilling the criteria established by Nunnally [35] and Bisquerra [36]. Furthermore, a Kaiser-Meyer-Olkin (KMO) test was carried out, obtaining a value of 0.740 [8]. In this study items 9, 37, 40, 41, 42 and 43 were utilized, which address questions related to the activities proposed by the teachers. Item 16 makes reference to the utilization of space by the boys and girls in the class. Item 35 analyzes if the teacher tries to make the groups of mixed gender. Class material is analyzed in item 22. The items 29 and 36 consider if the teacher takes into account sexist language. The influence of the issue of gender in evaluation of the students is considered in items 27 and 31. Lastly, feedback given by the teacher to the student is examined in items 30, 38, 39 and 44. To summarize, 17 of the 44 CACEF items were utilized in this work because these are the items that focus on the studied variables. The analysis of the Cronbach alpha values is 0.71 . It should be pointed out that in this work the items were not examined in function of the of dimension to which they belonged but rather that items that dealt with structural aspects of the class were analyzed. In the three dimensions of the questionnaire, therefore, there were items related with the activities of PE. In this way, there have not been any new dimensions created among the items that analyze the structural aspect of PE in itself, because the caseloads studied differ in function of the location and time of the session. Furthermore, there exist factors such as the analysis of material that are only studied by one item.

As for the students, they were assigned the Questionnaire of Perception of Equality and Discrimination in Physical Education (CPIDEF), developed by Cervelló et al. [18], which aims to assess students' perception of equality-discrimination in PE class. This questionnaire is composed by 19 Likert-type questions with values ranging from 1 to 10 . In this study, the scale was shown to obtain a Cronbach's alpha coefficient of 0.77 and a KMO value of 0.912 for the factor analysis carried out. In respect to the aspects analyzed by the questionnaire to the students, items $6,8,12,13,14$, 17 and 18 addressed the perception of the student about the activities proposed by the teacher. In item 3 the student considered mixed gender groupings. The student's appraisal of the material given by the teacher to each sex is analyzed in item 1. Items 5 and 9 relate to the sexist language used by the teaching staff. Student's perception of the influence of gender on evaluation was addressed in items 2, 4 and 10. Lastly, in items 7, 11, 14, 16 and 19 students evaluated the feedback that the teaching staff gives each gender. It should be noted that the utilization of space by students in the activities was a variable about which the teachers are consulted but not the students. This is due to the fact that the students are not able to observe and evaluate this factor while participating at the same time. As happened with the previous one, in this questionnaire the dimensions of perception of equality and discrimination were not followed, as this is not the objective of this work. Because of this, following 
the methodology employed in the previous instrument the items were examined in an individual manner and new dimensions were not created.

\subsection{Procedure}

Regarding the teaching staff, it was requested to the Provincial Department of the Autonomous Government of Andalusia in Jaén that they provided the distribution of PE teachers among the different schools within the province. Then every school was contacted and the Heads of Department provided their email address and their colleagues'. Three formats were used to send the questionnaire: hard copies; Word files sent by email in which the teaching staff had to complete the questionnaire and return it to the principle investigator and access to the questionnaire through the platform Moodle. The Moodle platform was created so that as the teaching staff gave their answers they were recorded in an Excel file, as can be seen in Valdivia, Quesada and López [37].

Regarding the students, a PE teacher or a managerial person was contacted in order to set a date to hand in the questionnaire and to obtain detailed information on which grades were going to participate. Subsequently, the questionnaires were submitted to all the students. There was always a member of the research team in the classrooms to resolve any doubts while filling in the questionnaire.

The schools' Parents Associations were asked for permission to carry out research. In addition, teachers participating in the study also gave their consent. Finally, the Ethics Committee of the University of Jaén gave their approval since ethical requirements were followed.

In all cases the participants in the study completed the questionnaire following the "one shot" technique, in which that questionnaire is filled out in one sitting and in the determined time.

\subsection{Statistical Analysis}

The data was entered into the statistics package SPSS 22.0 for their subsequent analysis. The results were obtained and discussed by comparing them to other national and international studies and conclusions were drawn. The statistics package SPSS version 22 was used to analyze the data. Descriptive statistics were estimated and Student's $t$-test, in order to identify the differences between sexes. Finally, it is important to note that all the statistical tests carried out present a confidence level of $95 \%$.

\section{Results}

The items answered by the students and teachers were very similar, in such a way that if an item for the teaching staff was, "I form student groups with an equal number of girls and boys," the item evaluating the students about group formation was, "normally we are organized so that in the same group there are boys and girls," to give an example. This way all of the methodological elements used by the instructors were also studied in the students. This was possible because in the designing and validation of the questionnaire for the teachers all of the items present in the CPIDEF were taken into account.

\subsection{Teaching Staff Results}

Teacher's results are indicated in Table 3.

The first results analyzed were those of items 9, 37, 40, 41, 42 and 43, which deal with questions related to class activities. In item 42 significant differences were found, in such a way that the female teachers (mean $=9.74)$ obtained a higher score than the male teachers (mean $=9.34)$. These results are related to Hypothesis 1.

Next and in relation to Hypothesis 2, the results of item 16 are displayed, which studies the space used by girls and boys during motor activities as perceived by the teaching staff. Significant differences were found between male and female teachers. In this case the male teachers (mean $=5.09$ ) achieved a higher score than the female teachers (mean $=4.2)$ in their opinion of how they concentrate on the control of the area used for motor activity. 
In respect to the results related to Hypothesis 3, no item has shown significant differences among teachers.

Table 3. Results of the items corresponding to the Questionnaire of Coeducational Aspects in Physical Education (CACEF).

\begin{tabular}{|c|c|c|c|c|}
\hline Factor Analyzed & Item & Mean & $\begin{array}{l}\text { Standard } \\
\text { Deviation }\end{array}$ & $p$ \\
\hline \multirow{6}{*}{$\begin{array}{c}\text { Activities } \\
\text { (Hypothesis } 1)\end{array}$} & $\begin{array}{c}9 \text { "Depending on the kind of activity, I find coeducation } \\
\text { difficult to manage" }\end{array}$ & 6.15 & 2.684 & $p=0.443$ \\
\hline & 37 "I promote participation of both boys and girls" & 9.62 & 0.723 & $p=0.394$ \\
\hline & $\begin{array}{c}40 \text { "I use both boys and girls as examples when explaining } \\
\text { physical activities" }\end{array}$ & 9.11 & 1.472 & $p=0.776$ \\
\hline & 41 "I suggest different activities according to gender" & 2.03 & 1.837 & $p=0.836$ \\
\hline & 42 "I give responsibilities as much to boys as to girls" & 9.44 & 1.114 & $p=0.002$ \\
\hline & 43 "I use the same rules for both boys and girls" & 9.34 & 1.294 & $p=0.064$ \\
\hline $\begin{array}{c}\text { Space } \\
\text { (Hypothesis 2) }\end{array}$ & $\begin{array}{l}16 \text { "In coeducation I focus on control of the area used for } \\
\text { motor activity" }\end{array}$ & 4.42 & 2.476 & $p=0.040$ \\
\hline $\begin{array}{l}\text { Class Groups } \\
\text { (Hypothesis 3) }\end{array}$ & $\begin{array}{l}35 \text { "I form class groups with equal numbers of girls } \\
\text { and boys" }\end{array}$ & 7.80 & 1.989 & $p=0.151$ \\
\hline $\begin{array}{c}\text { Material } \\
\text { (Hypothesis 3) }\end{array}$ & $\begin{array}{l}22 \text { "PE materials exist that intrinsically promote } \\
\text { sexist attitudes" }\end{array}$ & 3.64 & 2.762 & $p=0.072$ \\
\hline \multirow{2}{*}{$\begin{array}{l}\text { Evaluation } \\
\text { (Hypothesis 3) }\end{array}$} & 27 "Physical improvement varies according to gender" & 5.2 & 3.130 & $p=0.726$ \\
\hline & $\begin{array}{l}31 \text { "I devote different amounts of time to correcting } \\
\text { exercises, depending on gender" }\end{array}$ & 2.65 & 2.683 & $p=0.065$ \\
\hline \multirow{4}{*}{$\begin{array}{c}\text { Feedback } \\
\text { (Hypothesis 3) }\end{array}$} & 30 "I motivate and encourage boys and girls differently" & 3.31 & 3.016 & $p=0.066$ \\
\hline & 38 "I focus my attention equally on boys and girls" & 9.34 & 1.184 & $p=0.372$ \\
\hline & 39 "My interest in boys and girls varies according to gender" & 1.95 & 2.004 & $p=0.082$ \\
\hline & $\begin{array}{c}44 \text { "I take equally into account suggestions made by boys } \\
\text { and by girls" }\end{array}$ & 9.61 & 0.771 & $p=0.070$ \\
\hline \multirow{2}{*}{$\begin{array}{l}\text { Sexist Language } \\
\text { (Hypothesis 3) }\end{array}$} & 29 "I use a different tone when speaking to girls" & 8.09 & 2.469 & $p=0.476$ \\
\hline & $\begin{array}{c}36 \text { "I use the same verbal expressions for both boys } \\
\text { and girls" }\end{array}$ & 2.47 & 2.354 & $p=0.449$ \\
\hline
\end{tabular}

\subsection{Results of the Students}

Results of all the items are shown in Table 4. Those items with significant differences are specified below. The items that analyze the aspects related to class activities proposed by teachers from the students' perspectives (Hypothesis 4) were evaluated in items 6, 8, 12, 13, 15, 17 and 18 of the CPIDEF. Item 8 , "Do your teachers believe that boys and girls begin with different abilities in different activities" resulted in significant differences between boys and girls. It was the boys (boys mean $=6.19$; girls mean $=5.83$ ) that achieved a higher score when stating that teachers believe that boys and girls begin with different abilities depending on the activity. In item 13, significant differences were also found. In this case it was the girls (mean $=8.41$ ) that achieved a higher score than the boys (mean $=8.07$ ) when expressing their opinion that their teachers used boys and girls equally as examples. In respect to item 15 , the girls (mean $=8.90$ ) achieved higher scores than the boys (mean $=8.63)$, when responding as to whether their teachers think that boys and girls can learn and improve equally. In item 17 significant difference was found between sexes, in that the girls $($ mean $=8.85)$ more than the boys $($ mean $=8.47)$ believed that teachers apply the same rules in the activities for boys and girls. In relation to item 18 , the girls obtained higher scores (mean $=8.44)$ than the boys $($ mean $=8.09)$ in their belief that the teaching staff gives out responsibilities as much to girls as to boys. In this item, significant differences were found. 
The results related to Hypothesis 5 were the following. The items 2, 4 and 10 analyzed the perspective of the student in respect to evaluation in light of gender. Accordingly, in item 2, the female students (mean $=7.89$ ) reported higher scores than the boys (mean $=7.43)$, demonstrating a significant difference. In item 10 boys marked higher (mean $=8.5)$ than girls $(8.23)$ when giving their opinion about whether, when evaluating, the teachers have in mind the students' improvement in respect to their initial level. In continuation, teacher feedback was analyzed in items 7, 11, 14, 16 and 19. In this area, item 16 "Teachers listen equally to the suggestions given by girls and boys," statistically significant differences were shown, in that boys (mean $=8.55$ ) were those displaying higher scores than girls (mean $=8.04)$.

Lastly, the results related to Hypothesis 6 analyzing language related to items 5 and 9. Item 5, "Teachers utilize the same type of expressions speaking to boys as girls," resulted in significant differences. In this case girls scored higher $($ mean $=8.49)$ than boys (mean $=8.03)$. In respect to item 9 it was the boys (mean 4.17) who reported higher scores than the girls (mean $=3.69$ ) when giving their opinion as to whether their teachers use a different verbal tone for girls and boys. Accordingly, statistically different results were found.

Table 4. Results of the items corresponding to the Questionnaire of Perception of Equality and Discrimination in Physical Education (CPIDEF).

\begin{tabular}{|c|c|c|c|c|}
\hline Factor Analyzed & Item & Mean & $\begin{array}{l}\text { Standard } \\
\text { Deviation }\end{array}$ & $p$ \\
\hline \multirow{7}{*}{$\begin{array}{c}\text { Activities } \\
\text { (Hypothesis 4) }\end{array}$} & 6 "The teacher encourages boys' and girls' participation equally" & 9 & 1.863 & $p=0.606$ \\
\hline & $\begin{array}{l}8 \text { Do your teachers believe that Boys and girls begin with different } \\
\text { abilities in different activities }\end{array}$ & 6.02 & 3.049 & $p=0.047$ \\
\hline & $\begin{array}{c}12 \text { "The teacher suggests different activities depending } \\
\text { on gender" }\end{array}$ & 3.76 & 3.268 & $p=0.339$ \\
\hline & 13 "The teacher uses as examples both boys and girls" & 8.23 & 2.636 & $p=0.027$ \\
\hline & $\begin{array}{l}15 \text { "The teacher thinks that boys and girls can learn and improve } \\
\text { in the same way" }\end{array}$ & 8.75 & 1.984 & $p=0.020$ \\
\hline & 17 "The teacher uses the same rules both for boys and for girls" & 8.65 & 2.342 & $\mathrm{p}=.006$ \\
\hline & 18 "The teacher allocates responsibilities to both boys and girls" & 8.25 & 2.510 & $p=0.018$ \\
\hline $\begin{array}{l}\text { Class Groups } \\
\text { (Hypothesis 5) }\end{array}$ & $\begin{array}{l}3 \text { "Normally our teachers organize us so that there are boys and } \\
\text { girls in the same group" }\end{array}$ & 7.92 & 2.210 & $p=0.169$ \\
\hline $\begin{array}{c}\text { Material } \\
\text { (Hypothesis 5) }\end{array}$ & $\begin{array}{c}1 \text { "The teacher distributes material equally between boys } \\
\text { and girls" }\end{array}$ & 8.6 & 2.676 & $p=0.890$ \\
\hline \multirow{3}{*}{$\begin{array}{l}\text { Evaluation } \\
\text { (Hypothesis 5) }\end{array}$} & $\begin{array}{l}2 \text { "When evaluating, teachers do not have in mind whether the } \\
\text { student is a boy or a girl" }\end{array}$ & 7.64 & 3.023 & $p=0.009$ \\
\hline & $\begin{array}{l}4 \text { "The teacher thinks that the level of physical improvement can } \\
\text { be different depending on gender" }\end{array}$ & 5.76 & 3.301 & $p=0.779$ \\
\hline & $\begin{array}{l}10 \text { "When evaluating, the teacher gauges improvement in } \\
\text { comparison with the initial level" }\end{array}$ & 8.35 & 2.265 & $p=0.003$ \\
\hline \multirow{5}{*}{$\begin{array}{c}\text { Feedback } \\
\text { (Hypothesis 5) }\end{array}$} & 7 "The teacher's attention varies according to gender" & 4.12 & 3.321 & $p=0.071$ \\
\hline & $\begin{array}{l}11 \text { "The teacher shows different interest and concern, depending } \\
\text { on gender" }\end{array}$ & 4.19 & 3.235 & $p=0.085$ \\
\hline & $\begin{array}{c}14 \text { "The teacher motivates and encourages boys and } \\
\text { girls differently" }\end{array}$ & 4.04 & 3.280 & $p=0.090$ \\
\hline & $\begin{array}{l}16 \text { "Teachers listen equally to the suggestions given by girls } \\
\text { and boys" }\end{array}$ & 8.28 & 2.393 & $p=0.000$ \\
\hline & $\begin{array}{c}19 \text { "In terms of attention and correction, the teacher dedicates the } \\
\text { same amount of time to both boys and girls" }\end{array}$ & 8.39 & 2.401 & $p=0.117$ \\
\hline \multirow{2}{*}{$\begin{array}{l}\text { Sexist Language } \\
\text { (Hypothesis 6) }\end{array}$} & $\begin{array}{l}5 \text { "Teachers utilize the same type of expressions speaking to boys } \\
\text { as girls" }\end{array}$ & 8.24 & 2.473 & $p=0.000$ \\
\hline & 9 "The teacher adopts a different tone depending on gender" & 3.95 & 3.326 & $p=0.001$ \\
\hline
\end{tabular}




\section{Discussion}

In the case of PE, the methodology used must provide students with new body education experiences. Body education must be developed individually within a respectful environment among fellow students, regardless of their sex [3]. Castillo and Corral [12] make some important statements by claiming that male and female teachers use different methods for coeducation development, thus not contributing to the transmission of gender stereotypes in the same way. Following this argument, it is necessary to identify in a more exhaustive way where these differences lie, which is why the variable in this work is the methodology used by teachers.

This study aimed to analyze the existing differences between the sexes of the teaching staff when it comes to using coeducational methodologies in the PE class. Additionally, the differences in the students' perception of the teachers' work directed at gender equality was also assessed.

Regarding teaching staff, Rebollo et al. [22] and Piedra et al. [7] identify certain coeducational patterns in teachers which instill the creation of a gender culture among their students. Similarly, students may have stereotypes in relation to the teaching staff's gender and may expect different behavior depending on their teacher's sex [38]. It has been seen that PE teaching staff in particular show less coeducational behavior than teachers in other areas $[7,22]$.

Piedra et al. [6] state that female PE teachers present more coeducational attitudes than male PE teachers. The results of this study corroborate this argument, as is demonstrated in item 42 of the CACEF, which agrees with the conclusions of Piedra et al. [7]. Therefore, Hypothesis 1 is confirmed since female teachers report a higher score. Furthermore, several other studies [38,39] have already shown that teaching staff's behavior and their methodologies differ by gender. Accordingly, significant differences were found in the present study between male and female teachers only in items 16 (control of movement space) and 42 (assigning responsibility to students) and therefore, we cannot affirm that a global difference exists between male and female teachers.

In another vein, the study by Van Acker et al. [40] indicates that the teaching staff of both sexes utilizes the same activities regardless of the sex of the students. The results of our study found in item 16 show that male teachers favor coeducation in their control of movement space (Hypothesis $\neq 2$ ).

The student groupings used by the PE teaching staff tend to adhere to groups of mixed by ability in order to promote positive behavior [19]. The results in this study are however different from those obtained by Castillo et al. [13], who state that male teachers may form groups according to their students' sex, whereas female teachers do not use gender as a factor when forming groups. In relation to this, item 35 did not show significant differences between sexes, as both male and female teachers responded in the same way (Hypothesis $\neq 3$ ). It should be pointed out that the intervention of the teaching staff in student grouping is very important because without their action, the students organize themselves based on gender, there being no positive behaviors due to interaction between sexes [19].

In respect to the material that the teaching staff provides the students for the completion of activities, significant differences were not found between sexes (Hypothesis $\neq 3$ ). These results corroborate with Castillo et al. [13] in that they did not find evidence of discrimination by the teaching staff in these methodological elements. Other authors [24,41] indicate that the boys used better materials and more space.

The language, feedback and evaluation were other variables of the teaching staff analyzed in which significant differences were not found, thus not fulfilling Hypothesis 3.

In relation to the results of the students, it can be affirmed that the girls have a larger perception of equality in the action of the teaching staff than boys, as they marked a higher score in the items $13,15,17$ and 18 in the CPIDEF (Hypothesis $\neq 4$ ). These items address aspects such as the opinions of the teaching staff about the improvement and capacities of boys and girls, the use of the same rules for boys and girls and the assignment of responsibility to boys and girls. It is noteworthy that when teachers are consulted on assignment of responsibility to boys and girls, both genders get very high scores, with female teachers getting the highest score. In respect to item 13 consulting the students if their teachers use both male and female students as examples, it is the girls who get better 
results. Castillo et al. [13] indicated that boys are chosen by the teaching staff to do demonstrations, this being another example of sex discrimination. While the Castillo et al. [13] study was done with an observation sheet quantifying the times that girls and boys were chosen, the result of our study showed that girls do not perceive discrimination in these situations (Hypothesis $\neq 4$ ). On the other hand, item 8 , in which it is asked if they believe the teachers think that boys and girls start out the learning process with different initial levels, it is the girls that obtain a lower score and therefore perceive less discrimination (Hypothesis $\neq 4$ ).

As for the utilization of material by the teaching staff, there were no observed significant differences in item 1, not fulfilling Hypothesis 5 .

In regard to the analysis of groupings made by the PE staff, it was identified in the studies of Koçak, Harris, Kin, and Çiçek [42] and Auad and Corsino [43] that student groupings are an element of teachers' methodology in which situations of sex discrimination can be found. For this, in the interpretation of the results of item 3 of the CPIDEF it is important to note that there are no significant differences found between boys and girls when they give their opinion as to whether the teaching staff organizes them so that there are boys and girls in the same group (Hypothesis $\neq 5$ ). The intervention of the teacher in these situations is important because students tend to form groups of the same sex on their own as is indicated by Lyu and Gill [44].

In relation to the evaluation of the teaching staff, significant differences were found between the opinions of the boys and girls in items 2 and 10. Item 2 deals with whether the teachers have in account the sex of the students when evaluating them. On this occasion, the girls scored the highest, which confirms that they feel more discriminated against than the boys (Hypothesis $=5$ ). Item 10 addresses whether the teacher has the improvement of the students in mind when evaluating and it was the boys who reported higher in this category, therefore affirming again that girls feel more discriminated than boys in this situation (Hypothesis $=5$ ). When the teaching staff was consulted about this issue in items 27 and 31 of the CACEF, they did not demonstrate significant differences between males and females.

With respect to the feedback given to the students, Castillo and Corral [12] and Sánchez-Zafra, Zagalaz, Sánchez and Cachón-Zagalaz [45] affirm that teachers give more qualitative and quantitative information to boy students. The results of our study show that only in item 16 exist significant differences, in which boys score higher, affirming that the teaching staff listen equally to the suggestions of boys and girls. Therefore, items 7, 11, 14 and 19 not fulfill Hypothesis 5, while item 16 does not.

Lastly, in respect to the language used by the teaching staff, items 5 and 9 show significant differences between boy and girl students. In this case the girls showed higher scores when giving their opinion about whether their teachers use the same expressions when speaking to boys as to girls $($ Hypothesis $\neq 6$ ). On the other hand, when consulted whether the teaching staff uses a different voice tone with boys and girls, the boys displayed a higher score (Hypothesis $\neq 6$ ). As for the teaching staff, there were no significant differences between sexes in their analysis of sexist language. Teacher training in sexist language is an important aspect for a coeducational approach [46].

It can be seen that it is the female students who had a greater perception of equality in the different situations analyzed, while on the teaching staff's part there were hardly any differences found between male and female teachers.

This study cannot be finished without considering any future research that could be carried out following the present work.

Having brought focus on students, it could be of interest to assess equality and discrimination in populations with different cultures or origins, as well as in immigrant populations. In addition to that, it is also important for future research to compare the obtained data with the data found through the use of qualitative methodologies, such as observation or interviewing. Besides, no studies were found that aim to analyze equality or discrimination perception depending on age and grade, which is why the assessment of these two variables should ideally be carried out in future research. With the same 
instruments as those used in the present research, the study could be carried out in similar contexts and the results could be compared, with the aim of improving the methodologies used by teaching staff.

No studies have been found that analyze the methodology used by teachers according to their age and years of experience. It is therefore recommended by the authors of this study that future research aims to assess and develop these methodologies in terms of years of teaching experience. In that sense, among the future courses of action, it is necessary to develop some gender equality training plans to be followed by teachers all throughout their teaching career. Moreover, research must be done on activities that encourage equality among students and decrease their perception of gender discrimination.

Finally, it is necessary to put into operation intervention plans that encourage PE didactics from a gender perspective.

\section{Conclusions}

The conclusions of this research study provide new information about how PE teachers manage coeducation and how students perceive it, which was the aim of the study. In relation to the analyzed variables, conclusions are novel since this perspective had never been introduced in previous studies.

To conclude, there existed no difference between male and female teachers in relation to formation of groups, use of materials with boy and girl students, use of sexist language, evaluation of students and feedback given to boys and girls. For their part, the female teachers give more importance than male teachers in respect to imparting responsibilities equally to boys and girls. In respect to the male teachers, they focused more than their female counterparts in the control of motor activity space in the participation of both sexes.

In respect to the students, it is noted that in relation to the activities proposed by the teachers, the girls perceived to a larger degree than their male counterparts that the activities promote equality in the improvement of their capacities, the rules utilized and the assignment of responsibilities to girls as much as boys. There exist no differences between boys and girls in their perception of the material used by teachers, student grouping and feedback given by the teachers. In relation to evaluation, the girls thought that the teachers had the gender of the students in mind when making evaluations. On the other hand, the girls affirmed that their instructors used the same expressions when speaking to male and female students while the boys believed that the teaching staff uses a distinct tone when speaking with each gender.

Author Contributions: P.V.-M. and M.L.Z.-S. conceived the hypothesis of this study. P.V.-M., A.D.-S. and C.C. participated in data collection. D.M. analyzed the data. All authors contributed to data interpretation of statistical analysis. P.V.-M., M.L.Z.-S. and D.M. wrote the paper with significant input from A.D.-S. All authors read and approved the final manuscript.

Acknowledgments: No external funding was secured for this study.

Conflicts of Interest: The authors declare no conflict of interest.

\section{References}

1. Valdivia, P.A.; Sánchez, A.; Alonso, J.I.; Zagalaz, M.L. La coeducación en el área de Educación Física en España: Una reseña histórica. Cult. Cienc. Deporte 2010, 14, 77-83.

2. Khushbu, J.; Sharma, S.; Samani Chaitanya, P.; Viney, J. Influences of Gender, Religion, Dietary Patterns, and Mixed-sex Education on Aggressiveness in Children: A Sociodemographic Study in Municipal Primary Schools of South Delhi. Indian J. Public Health 2018, 62, 21-26. [CrossRef]

3. Azzarito, L.; Solmon, M. An Investigation of Students' Embodied Discourses in Physical Education: A Gender Project. J. Teach. Phys. Educ. 2009, 28, 173-191. [CrossRef]

4. Fisette, J.L. Exploring how girls navigate their embodied identities in physical education. Phys. Educ. Sport Pedagog. 2011, 16, 179-196. [CrossRef]

5. Torres, D. Propuesta de Programación Didáctica coeducativa en Educación Física en Educación Primaria: Un caso en la Sierra de Madrid. Retos Nuevas Tend. Educ. Fís. Deportes Recreac. 2005, 8, 43-49. 
6. Castillo-Andrés, O.; Campos-Mesa, M.C.; Ries, F. Gender equity in physical education from the perspective of achievement goal theory. J. Sport Health Res. 2013, 5, 57-70.

7. Piedra, J.; García-Pérez, R.; Rebollo, M.A.; Ries, F.J. Actitudes hacia la coeducación en Andalucía ¿Es el profesorado de Educación Física diferente? Rev. Investig. Educ. 2011, 9, 200-208.

8. Valdivia-Moral, P.; López-López, M.; Lara-Sánchez, A.; Zagalaz-Sánchez, M.L. Concepto de Coeducación en el Profesorado de Educación Física y metodología utilizada para su trabajo. Movimento 2012, 18, 197-217.

9. Valdivia-Moral, P.; Molero, D.; Campoy, T.J.; Zagalaz, M.L. Coeducational ideas in physical education teachers: Psychometric properties of a scale. Rev. Int. Med. Cienc. Act. Fís. Deporte 2015, 15, $269-288$.

10. Chalabaev, A.; Sarrazin, P.; Stone, J.; Cury, F. Do achievement goals mediate stereotype threat?: An investigation on females' soccer performance. J. Sport Exerc. Psychol. 2008, 2, 143-159. [CrossRef]

11. Kirk, D.; Oliver, K. The Same Old Story: The Reproduction and Recycling of Dominant Narrative in Research on Physical Education for Girls. Apunts 2014, 116, 7-22. [CrossRef]

12. Castillo, O.D.; Corral, J.A. El profesorado frente a la discriminación de género: Uso de la retroalimentación. Cult. Educ. 2011, 23, 487-498. [CrossRef]

13. Castillo, O.D.; Romero, S.; González, T.; Campos, M.C. Gender equity in physical education: The use of information. Sex Roles 2012, 67, 108-121. [CrossRef]

14. Chen, E.; Rao, N. Gender socialization in Chinese Kindergartens: Teachers' contributions. Sex Roles 2011, 64, 103-116. [CrossRef] [PubMed]

15. Lentillon, V.; Cogérino, G.; Kaestner, M. Injustice in physical education: Gender and the perception of deprivation in grades and teacher support. Soc. Psychol. Educ. 2006, 9, 321-339. [CrossRef]

16. Álvarez, B.; Costa, A.D. Goodbye to sex equality. A new approach to research on sex and gender. Educación XX1 2012, 15, 61-86.

17. Borges, F.; Belando, N.; Moreno-Murcia, J.A. Percepción de igualdad de trato e importancia de la educación física de alumnas adolescentes. Rev. Psicodidáct. 2014, 19, 173-189. [CrossRef]

18. Cervelló, E.; Jiménez, R.; Del Villar, F.; Ramos, L.; Santos-Rosa, F.J. Goal orientations, motivational climate, equality, and discipline of Spanish physical education students. Percept. Motor Skills 2004, 99, 271-283. [CrossRef] [PubMed]

19. Ramos-Nateras, F; Hernández-Mendo, A. Intervención para la reducción de la discriminación por sexo en las clases de Educación Física según los contenidos y agrupamientos utilizados. Rev. Esp. Educ. Fís. Deportes 2014, 404, 27-38.

20. Davis, K.L. Teaching for gender equity in physical education: A review of literature. Women Sport Phys. Act. J. 2003, 12, 55-65. [CrossRef]

21. Duffy, J.; Warren, K.; Walsh, M. Classroom interactions: Gender of teacher, gender of student, and classroom subject. Sex Roles 2001, 45, 579-593. [CrossRef]

22. Rebollo, M.A.; García-Pérez, R.; Piedra, J.; Vega, L. Diagnóstico de la cultura de género en educación: Actitudes del profesorado hacia la igualdad. Rev. Educ. 2011, 355, 521-546.

23. McKenzie, T.L.; Sallis, J.F.; Prochaska, J.J.; Conway, T.L.; Marshall, S.J.; Rosenguard, P. Evaluation of a Two Year Middle-School Physical Education Intervention: M-SPAN. Med. Sci. Sport Exerc. 2004, 36, 1382-1388. [CrossRef]

24. Cantó, R.; Ruiz, L.M. Comportamiento motor espontáneo en el patio de recreo escolar: Análisis de las diferencias por género en la ocupación del espacio durante el recreo escolar. Rev. Int. Cienc. Deporte 2005, 1, 28-45. [CrossRef]

25. Colwell, S. Feminisms and Figurational Sociolo Contributions to Understandings of Sports, Physical Education and Sex/Gender. Eur. Phys. Educ. Rev. 1999, 5, 219-240. [CrossRef]

26. Moreno, J.A.; Alonso, N.; Martínez-Galindo, C. Por una mayor coeducación e igualdad de sexo en la enseñanza de las actividades acuáticas. In II Congreso Internacional de Actividades Acuáticas; Moreno, J.A., Ed.; Instituto U. P. de Ciencias del Deporte: Murcia, Spain, 2005; pp. 136-159.

27. Valdivia-Moral, P. La Coeducación en la Educación Física Escolar. Análisis de las Teorías y Metodologías Asociadas del Profesorado y su Reflejo en el Alumnado. Estudio en la Provincia de Jaén. Ph.D. Thesis, Universidad de Jaén, Jaén, Spain, 2012.

28. Ariel, P. Juntos pero no revueltos: La Educación Física en clave de género. Cuad. Pesqui. 2004, 121, 59-76.

29. González, M. ¿Tienen sexo los contenidos de Educación Física Escolar? Transmisión de estereotipos de sexo a través de los libros de texto en la etapa de secundaria. Rev. Int. Med. Cienc. Act. Fís. Deporte 2005, 18, 77-88. 
30. Álvarez-Bueno, G.; Cano, S.; Fernández-Garcia, E.; López, C.; Manzano, A.; Vázquez, B. Guía Educación Física No Sexista; Ministerio de Educación y Ciencia: Madrid, Spain, 1990.

31. Castillo, O.D.; Romero, S.; González, T.; Campos, M.C. Gender equity in physical education. Motriz 2014, 20, 239-248. [CrossRef]

32. Koca, C. Gender interaction in coed physical education: A study in Turkey. Adolescence 2009, 44, 165-185. [PubMed]

33. Fox, D.J. El proceso de Investigación en Educación; Eunsa: Pamplona, Spain, 1981.

34. León, O.; Montero, I. Métodos de Investigación en Psicología y Educación; McGraw-Hill: Madrid, Spain, 2002.

35. Nunnally, J.C. Psychometric Theory; McGraw-Hill: New York, NY, USA, 1978.

36. Bisquerra, R. Introducción a la Estadística Aplicada a la Investigación Educativa. Un Enfoque Informático con los Paquetes BMDP y SPSSX; Promociones y Publicaciones Universitarias: Barcelona, Spain, 1987.

37. Valdivia, P.; Quesada, J.; López, M. Aplicación de cuestionarios mediante la plataforma moddle. Trances 2013, 5, 79-94.

38. Fasting, K.; Chronni, S.; Egil, S.; Knorre, N. Sexual harassment in sport toward females in three European countries. Int. Rev. Sociol. Sport 2011, 46, 76-89. [CrossRef]

39. Basow, S.A. Best and worst professors: Gender patterns in students' choices. Sex Roles 2000, 43, 407-417. [CrossRef]

40. Van Acker, R.; Carreiro da Costa, F.; De Bourdeaudhuij, I.; Cardon, G.; Haerens, L. Sex equity and physical activity levels in coeducational physical education: Exploring the potential of modified game forms. Phys. Educ. Sport Pedagog. 2010, 15, 159-173. [CrossRef]

41. Blández, J.; Fernández, E.; Sierra, M.A. Estereotipos de género, actividad física y escuela: La perspectiva del alumnado. Profr. Rev. Curric. Form. Profr. 2007, 11, 1-21.

42. Koçak, S.; Harris, M.B.; Kin, A.; Çiçek, S. Physical activity level, sport participation and parental education level in Turkish junior high school students. Pediatr. Exerc. Sci. 2002, 14, 147-154. [CrossRef]

43. Auad, D.; Corsino, L. Feminismos, interseccionalidades e consubstancialidades na Educação Física Escolar. Rev. Estud. Fem. 2018, 26, 1-13. [CrossRef]

44. Lyu, M.; Gill, G. Perceived physical competence, enjoyment and effort in same-sex and coeducational physical education classes. Educ. Psychol. 2011, 31, 247-260. [CrossRef]

45. Sánchez-Zafra, M.; Zagalaz-Sánchez, M.L.; Cachón-Zagalaz, J. Analisis de las conductas violentas en la escuela en función del género y el tipo de centro. ESHPA Educ. Sport Health Phys. Act. 2018, 2, 16-29.

46. Lastra, M. Gender perspective in initial training for early childhood education teachers: Notes about a research carried out in the degree of early childhood education at the University of Cantabria (Spain). Ex Aequo 2017, 36, 43-57. [CrossRef] 